\title{
RECOVERY OF INTEREST IN ENFORCEMENT Procedure IN THE REPUBLIC OF SLOVENIA
}

Accepted

13. 05.2021

Revised

04. 06. 2021

Published

30. 06. 2021

Keywords principle of formal legality, suitability of the enforceable title for the enforcement, two-stage enforcement procedure, interest, concretisation of obligations, certificate of enforceability

\author{
IRENA MERC \\ District Court in Maribor, Maribor, Slovenia \\ E-mail: merc.irena@gmail.com
}

\section{CORRESPONDING AUTHOR merc.irena@gmail.com}

\begin{abstract}
In Slovenian enforcement procedures, the principle of formal legality applies, so the enforcement court is bound by the enforceable title. The court must allow the enforcement of the claim as it follows from the enforceable title. The creditor also needs an enforceable title to claim interest. Interest arising from a Slovenian enforceable title shall be executed at the interest rate specified in Slovenian legislation. In the Republic of Slovenia, interest arising from a foreign enforceable title takes place at the interest rate determined by a foreign substantive provision. If the interest rate is determinable in a foreign enforceable title, the Slovenian Enforcement Court shall concretise the obligation by determining the interest rate determined by foreign law before issuing the writ of execution.
\end{abstract}




\section{$1 \quad$ Introduction}

The basic principle that applies in enforcement procedure in the Republic of Slovenia is the principle of formal legality, so the enforcement court is bound to the issued enforcement instrument. This principle thus refers to the rules for issuing an writ of execution (Rijavec, 2003: 63). Before deciding whether the court allows enforcement, all procedural and material preconditions for allowing enforcement must be examined, and the enforcement court also "looks" at the content of the enforceable title. This means that the enforcement court may examine in particular whether the claim, as asserted by the creditor in the application for enforcement, arises from the enforceable title, but may not examine the actual existence of a substantive claim (Juhart, 1974: 17). The principle of formal legality means that the enforcement court may not assess the concrete correctness and legality of the issued enforceable title (Rijavec, 2003: 63), but is bound by it despite its possible irregularities. The enforcement court must allow the claim to be enforced as it appears from the enforceable title.

The principle of formal legality is nowhere stated in the Act, but derives from the first paragraph of Article 17 of the Enforcement and Security Act (hereinafter: ZIZ), ${ }^{1}$ which states that the court shall allow enforcement based on an enforceable title. The enforcement court is bound by all enforceable titles, not only court decisions or notarial deeds, but also those enforceable documents for which a law, a ratified and published international treaty or an Act of the European Union (hereinafter: EU) states it is an enforceable title. An enforceable title is not necessarily the result of litigation or other procedures; the court is also bound by such enforceable titles as have not been issued by the court. If a question arises in the enforcement as to the correctness, legality or validity of the enforceable title, the debtor must state these grounds in the objection to the writ of execution. The enforcement court must consider certain grounds ex officio, but only when examining the objection filed (second paragraph of Article 55 of ZIZ). If the debtor does not object to the writ of execution, it shall become final, even if the decision

\footnotetext{
${ }^{1}$ Official Gazette of the Republic of Slovenia, No. 51/98, 11/99 - Dec. US, 89/99 - ZPPLPS, 11/01 - ZRacS1,75/02,87/02 - SPZ, 70/03 - Dec. US, 16/04,132/04 - Dec. US, 46/05 - Dec. US, $96 / 05$ - Dec. US, $17 / 06,30 / 06$ - Dec. US, 69/06, 115/06, 67/07 - ZS-G, 93/07, 37/08 - ZST-1, 45/08 ZArbit, 28/09, 51/10, 26/11,14/12,17/13 - Dec. US, 45/14 - Dec. US, 53/14, 58/14 - Dec. US, 50/15, 54/15, 76/15 - Dec. US, 11/18, 53/19 - Dec. US, 66/19 - ZDavP-2M, 23/20 - SPZ-B, 49/20 ZIUZEOP, 61/20 - ZIUZEOP-A, 203/20 - ZIUPOPDVE, 13/21, 36/21.
} 
based on which the writ of execution was issued has been modified. The principle of formal legality as a basic principle of enforcement procedure, does not give the enforcement court the power to decide "in case of dispute", but binds the enforcement instrument until it is finally annulled, revoked, amended or declared invalid, or the enforcement order is revoked. In such cases, the enforcement court shall, under Article 76 of the ZIZ, discontinue enforcement and cancel the enforcement measure carried out.

The principle of formal legality is also known in the countries of the former Yugoslav republics. Applying the principle of formal legality in enforcement based on an enforceable title expresses the presumption of the legal validity of public documents (Dika, 2007: 54), proving the truth of what is confirmed or determined in them (paragraph one of Article 224 of the Civil Procedure Act (hereinafter: ZPP). ${ }^{2}$ On one hand, the enforcement court is bound by an enforceable public deed or its content, but the enforcement court is exempt from the free assessment of evidence under Article 8 of ZPP due to the principle of formal legality. The enforcement court has no leeway to decide whether to change the content of the claim other than in the enforceable deed.

This principle means, in both the Slovenian and Croatian legal systems, the binding of the enforcement court to the enforcement deed in the enforcement procedure, and the prohibition of assessing the substantive justification of the claim under the enforcement deed. The enforcement court must assess only whether all formal preconditions for admission of enforcement determined by the law are met, and it must also determine the substantive preconditions. The substantive conditions for admission of enforcement also include the suitability of the enforceable title for enforcement. Article 21 of the ZIZ stipulates that an enforceable title "is suitable for enforcement if it states the creditor and the debtor and the object, nature, extent and time of performance of the obligations". If the enforceable title is so incomplete or defective that enforcement cannot be carried out, the court rejects the application for enforcement. In doing so, the court does not violate the principle of formal legality, but remains within its framework.

\footnotetext{
2 Official Gazette of the RS, No. 26/99, 96/02, 58/03 - Dec. US, 2/04, 2/04 - ZDSS-1, 69/05 - Dec. US, 90/05 Dec. US, 43/06 - Dec. US, 52/07, 45/08 - ZArbit, 45/08, 111/08 - Dec. US, 57/09 - Dec. US, 12/10 - Dec. US, 50/10 - Dec. US, 107/10 - Dec. US, 75/12 - Dec. US, 40/13 - Dec. US, 92/13 - Dec. US, 6/14, 10/14 - Dec. US, 48/14, 48/15 - Dec. US, 6/17 - Dec. US, 32/18, 16/19, 70/19 - Dec. US.
} 


\section{Recovery of interest based on Slovenian enforceable title}

\subsection{Statutory default interest}

The principle of formal legality also extends to ancillary claims, i.e. also to interest. For example, if interest on arrears was not awarded to the creditor in the enforceable title, then the enforcement court cannot allow its recovery either. However, if the interest is due to the creditor under the enforceable title, then the enforcement court will allow enforcement to recover the interest at the rate resulting from the enforceable title. If a court judgment is presented in the enforcement procedure, the interest must be based on the operative part of the court judgment and not on the grounds. The operative part of the judgment is a suitable enforceable title regarding interest if the interest is determined in such a way it is clear:

- out of which principal or individual principal they run,

- from when to when they run (date must specify the time of interest), and

- at what interest rate do they run (Iglič Stroligo 2009: 123).

Article 22 of the ZIZ provides for an exception to the principle of formal legality, as it allows the enforcement court to decide, on the proposal of the creditor or debtor, on the obligation to pay default interest at the modified rate, if the default interest under the enforceable title changes. ${ }^{3}$ Thus with interest on arrears, an exception to the principle of formal legality is allowed, and the enforcement court may allow enforcement at a rate different from that resulting from the enforceable title. In Slovenian case law, this provision is never applied, as in previous qualified proceedings default interest is awarded by reference to the "law". Statutory default interest is never defined in judgments of Slovenian courts so it specifies the percentage of the interest rate, as this is determined by the law and changes. Since it is always possible to determine or calculate interest on arrears, such an object of obligation is determinable and therefore such a claim for interest is admissible in case law. ${ }^{4}$

\footnotetext{
${ }^{3}$ Article 22 of ZIZ.

${ }^{4}$ Regarding the determinability of the interest liability in the enforceable title, the Supreme Court of the Republic of Slovenia (hereinafter: VSRS) issued a decision - VSRS Decision II Ips 557/2009 of 20 May 2010 (ECLI: SI: VSRS: 2010: II.IPS.557.2009).
} 
Thus with claiming interest based on a Slovenian enforceable title, it is mainly interest on arrears defined in Article 378 of the Code of Obligations (hereinafter: OZ). ${ }^{5}$ The first paragraph of Article 378 of the Civil Code says: "If the debtor is in arrears in the performance of a pecuniary debt, he shall owe default interest in addition to the principal sum." It is also possible to claim regular (contractual) interest in enforcement procedure, if it is recovering it based on a directly enforceable notarial deed. Default interest within the meaning of Article 378 paragraph 1 of the $\mathrm{OZ}$ is a consequence established by law, which occurs if the debtor does not fulfil the monetary obligation within the time limit set for its fulfilment (Šinkovec and Tratar, 2001: 367). Default interest may be determined by law, ${ }^{6}$ but the creditor and the debtor may agree that the default interest rate is lower or higher than the default interest rate set by law (contractual default interest). ${ }^{7}$ In Slovenian case law, the position has emerged that the term "statutory default interest" is sufficient, ${ }^{8}$ i.e. that it is an enforceable title suitable for enforcement in the interest part. This is the case where the creditor applies for enforcement because of interest, and the enforceable title says only that the debtor is liable to pay "statutory default interest" the rate of interest not determined as a percentage. Here, some say that the interest is determinable and its nominal amount will be determined by the court in the enforcement procedure. ${ }^{9}$ This will only apply to domestic enforceable title, as it is easy for a Slovenian court to calculate default interest under domestic law. Slovenian courts use a publicly available program to calculate statutory default interest, ${ }^{10}$ in which they can enter the debt, the amounts and dates of possible payments, and the date from which interest flows and the date of interest calculation. In this way, anyone can calculate ${ }^{11}$ statutory default interest under Slovenian law in a specific case. The program already considers the interest rate in a period, the method of interest calculation (conformal or linear), but does

\footnotetext{
${ }^{5}$ Official Gazette of the RS, No. 83/01, 32/04, 28/06 - Dec. US, 40/07, 64/16 - Dec. US, 20/18 - OROZ631.

${ }^{6}$ The second paragraph of Article 378 of the OZ states that the rate of interest on arrears is $8 \%$ per annum, unless a special law provides otherwise. According to the Statutory Default Interest Rate Act (hereinafter: ZPOMZO-1, Official Gazette of the Republic of Slovenia, No. 56/03, 135/03, 118/05, 55/06, 105/06), the prescribed interest rate for late payment is equal to the prime rate European Central Bank increased by 8 percentage points and is valid for a period of six months. The amount of the prescribed interest rate for default interest is published by the Minister of Finance in the Official Gazette of the Republic of Slovenia. Currently, i.e. for the period from 1 January 2021 to 30 June 2021, the statutory default interest rate is $8 \%$. Available at: https://www.uradni-list.si/glasilo-uradni-listrs/vsebina/2021-01-0109/visina-predpisane-obrestne-mere-zamudnih-obresti.

7 See Article 379 of the Code of Obligations.

8 VSRS Cpg 7/2016 of 15 July 2016 (ECLI:SI:VSRS:2016:CPG.7.2016).

9 Higher Court in Maribor (hereinafter: VSM) - VSM Decision I Ip 155/2012 of 15 May 2012 (ECLI:SI:VSMB:2012:I.IP.155.2012).

${ }_{10}$ The program is available on the VSRS website: http://izo.sodisce.si.

11 Although in the case of enforcement of a Slovenian enforceable title abroad, we cannot expect a foreign court or authority to use the said program in determining the Slovenian rate of statutory default interest.
} 
not check whether the interest exceeds the principal, according to the decision of the Constitutional Court of the Republic of Slovenia UI -300/04 of 2 March 2006. Such an examination of the conformity of a proposal for execution with these coercive rules must therefore be made by the enforcement court itself. It should be added that the court is not bound by the interest calculation submitted by the parties to the enforcement procedure, but is only obliged to verify the correctness of the respective calculation with this program. ${ }^{12}$ The interest calculation program is therefore only applicable to Slovenian enforcement titles, as it considers the interest rate determined by Slovenian legislation.

It should be clarified that statutory default interest under this program can be calculated only from the principal or debt in domestic currency and not from the principal in foreign currency. Regarding the statutory default interest payable by the debtor on debt in foreign currency, the VSRS issued a legal opinion on 22 June 1993 that the Statutory Default Interest Rate Act ${ }^{13}$ O, does not apply to debt in foreign currency and that the interest rates for these liabilities are not determined by any regulation. ${ }^{14}$ Statutory default interest was prescribed only for monetary claims in domestic currency until 1 January 2007, when the amendment ZPOMZO-1A ${ }^{15} \mathrm{O}$ precisely introduced the application of the statutory interest rates for foreign currencies also for monetary liabilities in foreign currencies. ${ }^{16}$ Thus, the interest calculation program considers the domestic currency (euro), so when calculating the statutory interest on arrears from a foreign currency, the foreign currency must first be converted into euro on the day of payment (according to the exchange rate of the Bank of Slovenia), which the currency conversion program makes possible, ${ }^{17}$ then the interest is calculated from the domestic currency. However, in the enforcement procedure, it is impossible to allow enforcement to recover statutory interest on arrears at the rate established under Slovenian law if the creditor applies for enforcement based on a foreign enforceable title. The provision of the first

\footnotetext{
12 VSM Decision I Ip 802/2010 of 20 July 2010 (ECLI: SI: VSMB: 2010: I.IP.802.2010).

13 Official Gazette of the Republic of Slovenia, Nos. 14/92 and 13/93.

${ }_{14}$ See Legal Opinion of the General Assemblies of the Supreme Court of the Republic of Slovenia and other courts, Legal Opinion, General Assembly of the Supreme Court of the Republic of Slovenia, 22 and 23 June 1993.

15 Official Gazette of the Republic of Slovenia, No. 105/2006.

${ }^{16}$ Higher Court in Ljubljana (hereinafter: VSL) - VSL in Judgment and Decision I Cp 346/2014 of 19 February 2014 (ECLI: SI: VSLJ: 2014: I. CP.346.2014).

${ }^{17}$ Also available at http://izo.sodisce.si.
} 
paragraph of Article 1 of ZPOMZO-1 ${ }^{18}$ applies only to Slovenian enforcement titles containing foreign currency, e.g. notarial deeds.

Regarding the definition of default interest, it should be added that the date should be defined primarily as the beginning of the period of interest, the end of which is usually read "until payment" in court decisions. Since we do not know in advance when the obligation will end, such a phrase is appropriate. The phrase "until payment" should not be read literally, as the obligation may end in other ways (e.g., set-off, cancelation of debt, but also because of the rule not ultra alterum tantum). Regardless of what is said in the operative part of the court's decision, the interest run must be interpreted as applying "until the termination of the obligation" (Iglic Stroligo 2009: 124). ${ }^{19}$ Nor is it wrong for the judgment of the court to record only the beginning of the run of interest and the end of the run is not defined. Clear interest flows and ceases to run when the obligation is discharged. Often such a decision is recorded when the court decides on the costs of the proceedings, whether in civil or in enforcement procedure, when the words "in case of default, statutory default interest commencing on the first day after the expiry of the period for voluntary performance of the obligation" are sufficient. Here, since the commencement of interest is not known at the time of judgment, ${ }^{20}$ it is necessary to note that interest accrues on the first day after the expiration of the time set for the payment of costs.

In enforcement procedure in the Republic of Slovenia, an application for enforcement is occasionally filed based on an older Slovenian court order that could not comply with the ultra alterum tantum prohibition that applied to statutory default interest in the period from the entry into force OZ until the entry into force of OZ -A (in the period from 1 January 2002 to 22 May 2007). If the unpaid default interest due has reached the principal within the specified time after issuing such a court order, the enforcement court must review accrued statutory default interest and also to limit it (subject to any rules governing its amount) ${ }^{21}$ with the writ of execution. When examining the conformity of the debt recovered with the claim for

\footnotetext{
${ }_{18}$ Paragraph 1 of Article 1 of the ZPOMZO-1: "The prescribed rate of interest on arrears is the annual rate at which pecuniary obligations are remunerated from the date of the debtor's default until the date of payment."

19 Thus also VSRS decision II Ips 983/2007 of 10 April 2008 (ECLI: SI: VSRS: 2008: II.IPS.983.2007).

${ }^{20}$ Indeed, what matters is when the party receives the court order, because that is when the period for voluntary performance of obligations begins to run.

${ }_{21}$ Above all, it is necessary to take into account the two decisions of the Constitutional Court of the Republic of Slovenia: U-I-300/04 of 2 March 2006 (ECLI:SI:USRS:2006:UI300.04) and Up-669/05 of 5 July 2007.
} 
enforcement, the enforcement court shall examine not only the principal claim but also whether the statutory default interest has been recognized in the creditor's enforceable title and shall apply of its own motion the provision of Article $376 \mathrm{OZ}$ in correct application of the substantive law. ${ }^{22}$ This means that the enforcement court calculates accrued statutory default interest helped by the program for calculating statutory default interest.

\subsection{Procedural interest}

A special feature in enforcement procedure is also the so-called procedural interest, which is regulated in Article 381 of the OZ. ${ }^{23}$ The procedural interest is defined as an exception to the prohibition of interest, which applies only to claims from the date on which the action was brought. In enforcement procedure, according to the principle of formal legitimacy, the creditor can only claim the interest he has recognized in the enforceable title. ${ }^{24}$ This is usually a provision contained in directly enforceable notarial deeds, namely that the debtor must also pay interest for the period from filing the application for enforcement. If the notarial deed has such a provision, it is a valid enforceable title, based on which execution may be allowed for the recovery of procedural interest. However, this position is not a generally accepted position in Slovenian case law. ${ }^{25}$ The negative position towards procedural interest is represented if law by the fact that procedural interest is tied only to the claim that leads to acquiring an enforceable title (litigation and related proceedings), but does not apply to already ongoing enforcement procedure based on the acquired enforceable title. ${ }^{26}$ However, precisely because with an enforceable notarial deed, the enforcement procedure are conducted based on a valid enforceable title in which

\footnotetext{
${ }^{22}$ Article 376 of the OZ: "Interest ceases to accrue when the sum of overdue but unpaid interest reaches the principal." The said provision has been deleted by amending the OZ-A.

${ }^{23}$ Article 381 of the OZ: "Default interest from unpaid interest can be claimed only from the day on which an application for its payment is filed with the court."

${ }^{24}$ Higher Court in Celje (hereinafter VSC) - VSC Decision I Ip 370/2016 of 14 October 2016 (ECLI: SI: VSCE:2016:I.IP.370.2016).

25 A dismissive attitude towards procedural interest in enforcement procedure was expressed by VSL Decision III Cp 297/2004 of 18 February 2004 (ECLI:SI:VSLJ:2004:III.CP.297.2004), VSL Decision III Ip 963/2013 of 24 April 2013 (ECLI:SI:VSLJ:2013:III.IP.963.2013), VSL Decision I Ip 3183/2014 of 15 October 2014 (ECLI:SI:VSLJ:2014:I.IP.3183.2014), VSL Decision I Ip 2608/2015 of 26 August 2015 (ECLI:SI:VSLJ:2015:I.IP.2608.2015), VSM Decision I Ip 250/2016 of 12 September 2016 (ECLI:SI:VSMB:2016:I.IP.250.2016), VSM Decision I Ip 379/2016 of 12 September 2016 (ECLI:SI:VSMB:2016:I.IP.379.2016), VSM Decision I Ip 445/2017 of 14 July 2017 (ECLI:SI:VSMB:2017:I.IP.445.2017) and VSM Decision I Ip 370/2019 of 3 July 2019(ECLI:SI:VSMB:2019:I.IP.370.2019).

${ }^{26}$ VSM Decision I Ip 445/2017 of 14 July 2017 (ECLI:SI:VSMB:2017:I.IP.445.2017).
} 
the procedural interest is determined, enforcement must be permitted for that interest (Ljubimski, 2011: 8). The creditor can no longer lodge a claim based on which he would obtain an enforceable title for the recovery only of procedural interest, since he already has an enforceable title. ${ }^{27}$

Slovenian case law has thus developed another exception to the principle of formal legality and has taken ${ }^{28}$ the position in some decisions that a creditor cannot claim a procedural interest in an application for enforcement based on an enforceable title even if it is stipulated in a directly enforceable notarial deed, as such a contractual provision is void (see also Ekart and Rijavec, 2019: 50). The essential question that arises in connection with the assertion of procedural interest is:

- whether, under the principle of formal legality, the court is bound by an enforceable title and must grant the creditor's request to recover procedural interest if it is included in the enforceable title,

- whether it is an exception to the principle of formal legality and the enforcement court must refuse to recover such interest even if it arises from an enforceable title, since procedural interest is only linked to a claim giving rise to an enforceable title (i.e. civil and related proceedings).

If one follows the view that with a directly enforceable notarial deed in which the parties have agreed on a procedural interest, it is a case of an inadmissible agreement contrary to the order of compulsion (partial nullity), then this partial nullity must be considered when allowing enforcement. The principle of formal legality as a standard of value is therefore not absolute in terms of content, but is mitigated with directly enforceable notarial deeds, particularly if one party (e.g. a consumer with a credit agreement) is subordinate to the other party (bank) regarding bargaining power. Since directly enforceable notarial deeds do not have the effect of finality and prior judicial review of compliance with domestic public policy is not guaranteed, the strictness of the principle of formal legality is relaxed in such cases..$^{29}$ This position

\footnotetext{
${ }^{27}$ Cf. VSL Decision II Ip 1582/2017 of 7 June 2017 (ECLI:SI:VSLJ:2017:II.IP.1582.2017).

${ }_{28}$ The decisions of the Higher Court in Maribor are of particular importance: VSM Decision I Ip 445/2017 of 14 July 2017 (ECLI:SI:VSMB:2017:I.IP.445.2017), VSM Decision I Ip 370/2019 of 3 July 2019 (ECLI:SI:VSMB:2019:I.IP.370.2019).

${ }^{29}$ See point 18 of the reasoning of decision VSM I Ip 370/2019 of 3 July 2019 (ECLI:SI:VSMB:2019:I.IP.370.2019).
} 
was also taken by the Court of Justice of the EU in Case C-407/2018, ${ }^{30}$ in which, on the initiative of the High Court in Maribor, it ruled that the principle of the effectiveness of Union law in relation to Council Directive 93/13/EEC of 5. April $1993^{31}$ unfair terms in consumer contracts must be interpreted as contrary to national law and that the Slovenian Enforcement Court has the possibility to postpone the enforcement if the notarial deed is declared void in the civil proceedings, otherwise the real estate enforcement could be completed before the judgment of the civil court. By assessing the principle of effectiveness, the Court of Justice of the EUhas thus guaranteed the debtor (consumer) the right to effective legal protection, i.e. until the decision on the merits in the civil proceedings on unfair terms in the mortgage loan agreement. It can also be deduced from this decision that the principle of formal legality is relaxed in the assessment of directly enforceable notarial deeds that (may) contain unfair contractual clauses. The creditor's right of enforcement is therefore not protected in such cases, even if the creditor has an enforceable title - a directly enforceable notarial deed. The Court of Justice of the EU has emphasized this Directive provides the debtor (consumer) with effective legal protection, allowing for a possible ex officio control of the possible unfairness of contractual terms. ${ }^{32}$ Thus, in cases of unfair contract terms in enforceable notarial deeds, the enforcement court has to deal with consumer protection ex officio.

\subsection{Two-phase enforcement procedure}

The Slovenian enforcement procedure knows the phase of granting and the phase of enforcement. When granting enforcement, it is the duty of the enforcement court to verify whether the creditor's interest (statutory default, contractual default, ordinary default, procedural default), the recovery of which it proposes, has also been recognized in the enforceable title. However, in the recovery of contractual default and contractual ordinary default interest, it is the creditor's responsibility to set out his claim in a structured manner in the enforcement application. The creditor must also state in the enforcement application the facts that support the calculation of the interest (amount of the principal claim; due date of the claim from which the

\footnotetext{
30Judgment SEU C-407/18 of 26 June 2019 Aleš Kuhar and Jožef Kuhar v. Addiko Bank d.d (ECLI:EU:C:2019:537).

${ }^{31}$ Council Directive 93/13/EEC of 5 April 1993 on unfair terms in consumer contracts (OJ L 95, 21 April 1993).

32 See also judgments SEU C-49/14 of 18 February 2016 Finanmadrid EFC SA v J. V. A. Zambrano, M. J. G. Zapata, J. L. A. Zambrano, M. E. C. Merino (ECLI:EU:C:2016:98) and C-176/17 of 13 September 2018 Profi Credit Polska S.A. w Bielsku Białej v Mariusz Wawrzosek (ECLI:EU:C:2018:711).
} 
interest is calculated). ${ }^{33}$ If the creditor does not present his claim in a structured manner, the enforcement court will reject the application for enforcement because it is impossible to verify that the recovered claim corresponds to the claim under the enforceable title. Partially, the court will reject the application for enforcement into the interest part if the interest is not recognized in the enforcement title, and where it is recognized but not specified (from which principal it flows, from when it runs and in what amount), which would constitute a corresponding enforceable title.

\section{Recovery of interest based on a foreign enforceable title}

\subsection{General}

In enforceable title in the Republic of Slovenia, the creditor may apply for enforcement based on an enforceable title from an EU Member State or based on an enforceable title from a non-EU country. Regardless of the origin of the foreign enforceable title, there are problems in the enforcement procedure, especially in enforcing the interest part of the claim. If the prescribed European forms ${ }^{34}$ are completed so the interest rate is calculated according to a foreign law, but the interest rate is not specified in the form, the question arises whether the enforcement court must specify the interest rate in advance or summon the creditor to specify the enforcement request in this part. Equally problematic are foreign enforcement orders from which the legal basis is not derived, but only from the fact that the creditor is entitled to "statutory default interest".

Enforcement of the interest part of the claim arising from a foreign enforceable title is carried out in the Republic of Slovenia under the rules of the ZIZ and the principle of formal legality. Regarding the amount and course of interest, the Slovenian Enforcement Court is bound to a foreign enforceable title, which in consequence means that if the default interest rate is determined according to foreign law,

\footnotetext{
33 The same is true in the case of VSL Decision II Ip 2798/2013 of 9 October 2013 (ECLI:SI:VSLJ:2013:II.IP.2798.2013).

${ }^{34}$ The standard form contained in Article 9 of Regulation (EC) No. 1049/2001 of the European Parliament and of the Council has been analyzed. Regulation (EC) No. 805/2004 of the European Parliament and of the Council of 21 April 2004 creating a European Enforcement Order for uncontested claims (hereinafter: Regulation 805/2004/EC (OJ L 143, 30 April 2004)) and the standard form contained in Article 53 respectively in Article 60 of Regulation (EU) No. 1215/2012 of the European Parliament and of the Council of 12 December 2012 on jurisdiction and the recognition and enforcement of judgments in civil and commercial matters (recast) (hereinafter: Regulation BU Ia (OJ L 351, 20 December 2012).
} 
enforcement will take place in the Republic of Slovenia at the interest rate determined according to foreign law. This follows directly from the principle of formal legality (binding to an enforceable title), but also from the provision of Article 94 of the Private International Law and the Procedural Act (hereinafter: ZMZPP), ${ }^{35}$ which states that "a foreign court decision is assimilated to a court decision of the Republic of Slovenia with the same legal effect as a domestic court decision only if it is recognized by the court of the Republic of Slovenia". ${ }^{36}$ This is the system of equality - a foreign judgment is equated in its effects with a domestic judgment, so a foreign court judgment cannot be given more effects than it has under the law of the home state, even though a Slovenian judgment would have them. In the Republic of Slovenia, a creditor cannot be satisfied to a greater extent than determined by the substantive law of the country from which the enforceable title originates (Rijavec, 2008: 997-998).

With a proposed enforcement based on a foreign enforceable title, two situations are possible, in the first there is a foreign enforceable title in the Republic of Slovenia where the principal is written in euros (i.e. in the national currency), and in the second situation it is a foreign enforceable title where the principal is written in a foreign currency (e.g. an enforceable address from the Republic of Croatia containing the HRK currency), and in both cases the creditor also may have statutory default interest if the debtor's default occurs, with an indication of which law was responsible for this. In none of the situations it is possible to apply the default interest rate according to ZPOMZO-1, but to enforce the interest part of the claim from both enforcement titles it is necessary to start from the fundamental principle of the enforcement procedure, i.e. the principle of strict formal legality, which extends also to the interest. If the interest rate is determined according to foreign legislation, the interest part of the claim decided in a foreign enforceable title is enforced in the Republic of Slovenia at the interest rate determined by the foreign substantive provision. This is also the position of Slovenian case law. ${ }^{37}$ The determination of the correct default interest rate is a matter of substantive law, ${ }^{38}$ and the enforcement court allows enforcement for that default interest rate, as shown by the enforceable title. If the interest rate in the enforceable title is not set in

\footnotetext{
35 Official Gazette of the Republic of Slovenia, No. 56/99, 45/08 - ZArbit, 31/21 - Dec. US.

${ }^{36} \mathrm{~A}$ foreign court decision is also considered to be a court settlement or a decision of another body that is equivalent to a court decision or a court settlement in the country of origin, if it regulates the relations arising from Article 1 of the ZMZPP (second and third paragraphs of Article 94 of the ZMZPP).

37 VSRS Decision Cpg 7/2016 of 15 July 2016 (ECLI:SI:VSRS:2016:CPG.7.2016).

38 VSRS judgment III Ips 159/99 of 17 November 1999.
} 
percentage, the Slovenian court must look into foreign regulations and only set the interest rate for default interest according to foreign law. Thus, in allowing enforcement, the enforcement court must be "loyal" to the enforceable title, ${ }^{39}$ and since it does not decide on the claim, it may enforce nothing other than what is set in the enforcement title, which is what would happen if the court allowed enforcement according to the interest rate determined by Slovenian legislation. If the creditor applies for the recovery of the principal claim with statutory interest on arrears according to Slovenian substantive law, he demands something different from what was awarded to him by the enforceable title, ${ }^{40}$ so that in such a case the application to enforce the interest part must be rejected.

For claiming interest based on a foreign enforceable title, from which the term "statutory default interest" or "statutory interest" is derived, the Slovenian Enforcement Court will run into difficulties, as it (in principle) does not know the foreign law. In Slovenian civil proceedings, the principle applies that the court knows the law (including foreign law) ex officio (iura novit curia), ${ }^{41}$ so the question arises whether the enforcement court must determine interest based on the enforcement of the interest part of the claim ex officio. It is determined by foreign legislation whether it does not have to determine this and can reject the application to enforce the interest part as unsuitable for enforcement. A prerequisite for allowing enforcement is that the enforceable title is suitable for enforcement the debtor's obligation must be defined or at least determinable in the enforceable title. When "statutory default interest" is included in a foreign enforceable title, the suitability of the enforceable title is not sufficient because it is not clear what interest is covered by the statute, and thus the interest rate cannot be determined. The situation is different if the legal basis, i.e. the provision according to which the interest can be calculated, is written down in a foreign enforceable title. Here, however, the interest is determinable and the enforcement court only has to determine (by inquiring with the competent foreign authority) interest or the interest rate and then allow enforcement. The Slovenian Enforcement Court is therefore the one that concretises the interest rate set in the foreign enforcement order before issuing the enforceable title.

\footnotetext{
${ }^{39}$ VSM Decision I Ip 1366/2015 of 30 September 2015 (ECLI:SI:VSLJ:2015:I.IP.1366.2015).

40 VSM Decision I Ip 104/2009 of 18 March 2009 (ECLI:SI:VSLJ:2009:II.IP.104.2009).

${ }^{41}$ VSRS judgment II Ips 917/2006 of 16 April 2009 (ECLI:SI:VSRS:2009:II.IPS.917.2006).
} 


\subsection{EU law}

The question of who determines interest in proceedings for issuing a European order for payment under Regulation 1896/2006/EC, a party or a court of its own motion, ${ }^{42}$ has also been addressed by the Court of Justice of the EU in its preliminary ruling and decided in Case C-215/11 (S Syrocka case) that a party in an application for a European order for payment only has to clearly indicate the interest rate and the period for which such interest is claimed (the date from which such interest is claimed), but not the exact amount of (calculated) interest. However, the national court can choose a concrete form only of filling in the European order for payment under Annex V of Regulation 1896/2006/EC by informing the defendant in no uncertain terms of the decision requiring the claimant to pay the interest accrued up to payment of the principal claim, clearly defining the interest rate and the date from which such interest is claimed. In the reasoning of its decision, the Court added that Regulation 1896/2006/EC only regulate the procedural aspects of the order for payment procedure and all issues related to the interest that can be claimed in the European order for payment procedure are regulated by law. The Court of First Instance has found that the Regulation applies to the relationship between the parties out of which the specific claim arises. ${ }^{43}$ Therefore, even when issuing a European order for payment, the Court of Justice of the EU must rely on the substantive law of the country from which the party's claim originates.

\subsection{Certificate of enforceability under Regulation 805/2004/EC and Regulation BU Ia}

That the interest part of the claim is determined by the substantive law of the Member State follows mutatis mutandis also from Regulation 805/2004/EC, which prescribes in Article 16(c) that if interest is also claimed from the principal claim, the interest part of the claim shall be determined with the indicated interest rate and interest period, unless the statutory interest of the Member State of origin is automatically added to the principal claim. In the application or form completed by the court of origin in issuing a certificate under Regulation 805/2004/EC, the

\footnotetext{
${ }^{42}$ Regulation (EC) No. 1896/2006 of the European Parliament and of the Council of 12 December 2006 on the initiation of proceedings for a European order for payment (OJ L 399 of 30 December 2006).

${ }^{43}$ See the reasoning of the judgment of the Court of Justice of the EU, Case C-215/11, of 13 December 2012 Iwona Szyrocka v SiGer Technologie GmbH (ECLI:EU:C:2012:794).
} 
interest part of the claim can be specified by indicating the interest rate (in $\%$ or $\%$ above the base rate ECB) and the date from which the interest run, which facilitates enforcement in another Member State. In this way, the certification of the enforceable title as a European enforceable title already makes it possible to specify the interest (Rijavec et al., 2012: 88). If the interest rate in the certificate according to Regulation $805 / 2004 / \mathrm{EC}$ is also only vaguely specified, e.g. only as "statutory default interest", this will cause the same problems for the court in the executing state of enforcement of a foreign enforceable title which specifies interest vaguely and is not certified as a European enforceable title (see also Sladič, 2013: 353).

European forms (European Enforcement Order certificate) can thus reduce the possibility of a foreign authority certifying a defective enforceable title. The forms contain information on the claim decided in the enforceable title (principal, interest and costs). If the information in the enforceability certificate under Regulation 805/2004/EC does not correspond to the content of the enforceable title, such a certificate is only valid as a supplementary explanation, e.g. regarding the interest rate, but is not bound by it. ${ }^{44}$ The enforcement court is always bound by the content determined by the foreign enforceable title. To be enforceable in the Republic of Slovenia, a claim in a foreign enforceable title must also be determined numerically or at least be determinable according to objective criteria regarding the principal claim, interest and costs of the procedure. ${ }^{45}$ Therefore, even a certificate under Regulation 805/2004/EC cannot substitute for the substantive defects of a judicial decision. However, if an order of enforceability under Regulation 805/2004/EC is granted, the deficiency of a judicial decision cannot be evidence of "statutory default interest". According to the case law of the Court of Justice of the EU, Article 6 of Regulation 805/2004/EC is to be understood as meaning that only a judge can issue such a certificate, ${ }^{46}$ so he can also specify the claim in the interest part. A certificate under Regulation 805/2004/EC thus confers effects on a judicial decision which it did not have previously (Rijavec et al., 2018: 119). By filling in the data in the certificate according to Regulation 805/2004/EC the claim in the interest part

\footnotetext{
${ }^{44}$ VSM Decision I Ip 24/2019 of 20 March 2019 (ECLI:SI:VSLJ:2019:II.IP.24.2019). In the present case, the Italian court indicated the percentage of the interest rate in the certificate pursuant to Regulation 805/2004/EC and limited the term of the interest until the date of issuance of the certificate, although the creditor was entitled to interest under the enforceable title until the claim was settled.

45 See point 12 of the reasoning of the Decision VSL II Ip 24/2019 of 20 March 2019 (ECLI:SI:VSLJ:2019:II.IP.24.2019).

${ }^{46}$ Case C-300/14 of 17 December 2015 Imtech Marine Belgium NV v Radio Hellenic SA (ECLI:EU:C:2015:825).
} 
becomes identifiable and the enforceable title is suitable for enforcement in the Republic of Slovenia.

The same applies to a certificate of enforceability under Regulation BU Ia. The executing State is bound by such a certificate and by the content of the judgment. According to Article 52 of Regulation BU Ia it is not permissible to examine the content of a court decision. If a particular judgment is considered sufficiently definite in the country of origin (the competent authority has issued an order of enforcement), it may be enforced in the country of enforcement even if it does not meet the conditions specified. The effects of enforceability cannot be limited. If a defective obligation in the enforceable title occurs or in the order of enforcement, the law of the State of enforcement shall apply in the State of enforcement regarding the concretisation of such an enforceable title. The problem may arise where the State of origin considers an enforceable title to be sufficiently specific, issues an order of enforcement and the enforcement authorities in the State of enforcement are not empowered to concretise such an enforceable title. E.g. in Germany the content of the enforceable claim must result from the operative part of the judgment. If the operative part of the enforceable title is not sufficiently specified (e.g. interest does not result explicitly from the operative part of a court decision), the enforcement authorities must refuse the enforcement (Wiedemann, 2017: 279). The enforcement procedure under Article 41 of Regulation BU Ia shall be conducted under the rules of the law of the executing State. The Slovenian Enforcement Court can specify the obligations if it has all the information in the certificate, but there may be problems. It is therefore appropriate for a foreign authority to specify its obligations when completing such a form so there is no doubt later in another Member State about the content of the enforceable title. ${ }^{47}$

\section{Comparison with the Republic of Austria and the Republic of Croatia}

Slovenian jurisprudence assumes the payment of "statutory default interest" and does not include a percentage of the interest rate. Croatian legal theorist Dika is of the opinion that such claims for payment of "statutory default interest" are inadmissible without specifying the interest rate and that such practice is contrary to Croatian enforcement law. The claim for payment of interest must be set out in the claim, it

\footnotetext{
${ }^{47}$ See also VSM Decision I Ip 145/2021 of 31 March 2021 (ECLI:SI:VSMB:2021:I.IP.145.2021).
} 
must at least be defined in such a way as to indicate the interest rate at which the interest is to be paid. The application must be defined in qualitative and quantitative terms. An application that does not contain a specific claim does not contain everything necessary for its consideration, so such an application should be sent back for correction or completion (Dika, 2009: 73). Common practice in Croatia court judgments, and other enforcement titles, do not define the obligation to pay interest by specifying the interest rate, but by statutory default interest or whether the interest refers to another regulation (e.g. the Act) or a general Act of a legal person (e.g. a bank). The enforceable title thus decided on the basis (existence of an obligation to pay interest), but did not specify the criteria according to which the interest could be calculated. At a consultation on 1 and 2 June 1998, the Supreme Court of the Republic of Croatia ruled that a claim is determined in the interest part (with statutory interest) if it contains a regulation instead of a numerical interest rate (Dika, 2009: 85-86). Croatian court decisions are thus accompanied by a reference to the law according to which interest is to be calculated.

In the Republic of Austria, court decisions always indicate an interest rate in percent. The Austrian Civil Code (hereinafter: ABGB) ${ }^{48}$ sets out in $\$ 1000$ the general rate of interest if it is not agreed or does not follow from the law, namely $4 \%$ per annum. ${ }^{49}$ Following the adoption of Directive 2011/7/EU of the European Parliament and the Council of 16 February 2011 on combating late payment in commercial transactions, ${ }^{50}$ which entered into force on 15 March 2011, Austria has increased the interest rate in commercial transactions from the previous $8 \%$ above the base rate to now $9.2 \%$. $\ 456$ of Austrian Commercial Code (hereinafter: UGB) ${ }^{51}$ provides that the interest rate for late payment of receivables is 9.2 percentage points above the base rate and that the interest rate for each half year is applicable. It further provides that if the debtor is not responsible for the delay, he shall pay only the interest mentioned in the first paragraph of $\$ 1000$ of $A B G B$, i.e. only $4 \%$.

\footnotetext{
48 Allgemeines bürgerliches Gesetzbuch, JGS No. 946/1811, as last amended BGBl. I No. 131/2020.

49 S 1000 ABGB: "An Zinsen, die obne Bestimmung der Höhe vereinbart worden sind oder aus dem Gesetz gebühren, sind, sofern gesetzlich nicht anderes bestimmt ist, vier vom Hundert auf ein Jahr zu entrichten."

${ }^{50}$ Directive 2011/7/EU of the European Parliament and of the Council of 16 February 2011 on combating late payment in commercial transactions Text with EEA relevance (OJ L 48, 23 February 2011).

51 Unternehmensgesetzbuch, dRGBl. S 219/1897, as last amended BGB1. I No. 63/2019.
} 
In the Republic of Austria, therefore, there is no uniform rate of statutory default interest, but it depends on whether the debtor is a legal person or a consumer, or whether the debtor, who is a legal person, is liable for the default. Interest on arrears is thus regulated in two laws (ABGB and UGB). Therefore, even in the Republic of Austria, it is not sufficient for the court to note "with statutory interest rates", as it is not known which interest applies and the interest rate. Most other legal systems in Europe (including Croatia) also distinguish between the interest rate for civil and commercial matters (Juhart, 2005: 61). The Republic of Slovenia does not have such a distinction, but has a uniform interest rate, which is $8 \%$ for both legal entities and natural persons (consumers) and is regulated in ZPOMZO-1. The Republic of Croatia has an interest rate regulated in Article 29 of the Civil Obligations Act. ${ }^{52}$ In contrast to Slovenian and Croatian court decisions, it is characteristic of Austrian court decisions that the interest part of the claim contains an indication of the interest rate.

A creditor applying for enforcement in the Republic of Austria must designate the application, as enforcement is only permissible under $\ 7(1)^{53} \mathrm{EO}^{54}$ if the application is designated in the application for enforcement as being "covered" by an enforceable title (Rechberger, Oberhammer, 2009: 48-49). The creditor cannot demand more than results from the enforceable title (Neumayr, NunnerKrautgasser, 2018: 91). Austrian law also recognizes the "attachment to a claim arising from an enforceable title", so the legal systems of Austria, Slovenia and Croatia are essentially identical regarding binding to an enforceable title. However, the Austrian legal system knows the exception to the above-mentioned "binding to the enforceable title", namely that the court may allow the enforcement of interest on the costs of the proceedings, even if they do not originate from the enforceable title. The exception is provided for in $\int 54 a$ (2) ZPO, ${ }^{55}$ which will be explained below.

\footnotetext{
52 Zakon o obveznim odnosima (Official Gazette 41/08, 35/05, 41/08, 125/11, 78/15, 29/18).

53 Paragraph.

${ }^{54}$ Exekutionsordnung (EO), Gesetz vom 27. Mai 1896, über das Exekutions- und Sicherungsverfahren, StF: RGBl. Nr. 79/1896, last amended BGBl. I No. 100/2016.

55 Zivilprozessordnung (hereinafter: ZPO), RGBl. No. 113/1895, as last amended BGBl. I No. 109/2018.
} 
In cases involving the enforcement of foreign enforcement titles, the Supreme Court of the Republic of Austria has ruled that the enforcement of a claim under a foreign enforceable title cannot give the foreign enforceable title greater effect in the country of enforcement than in the country of origin. ${ }^{56}$ As an example, permission of enforcement can be given if the enforceable title does not trigger interest on the awarded procedural costs. The Austrian civilian procedure order (ZPO) contains the provision $\ 54 \mathrm{a} / 2$, which allows the creditor to claim statutory interest on the costs part of the enforceable title, even if the interest does not arise from the order for costs. The creditor can only claim this if the costs of the proceedings have not been paid by the time the costs part of the court decision becomes enforceable $(\mathbb{S} 54 \mathrm{a} / 1$ $\mathrm{ZPO})$. However, the provision of $\int 54 \mathrm{a}$ of the ZPO does not apply to such costs in the enforcement procedure. It is important to note that the said provision is not procedural, but is a substantive legal basis for the creditor to formulate such a claim in the enforcement procedure. This provision only applies to domestic (i.e. Austrian) enforceable title. However, with foreign enforceable title in Austrian enforcement procedure, the obligation to pay interest on the costs of the proceedings must arise expressly from the operative part of the foreign enforceable title. Thus, if a foreign enforceable title does not contain in its legal order a provision comparable to the Austrian $\$ 54 \mathrm{a}$ ZPO, the Austrian court cannot allow the enforcement of interest on litigation costs based on such a foreign enforceable title, unless such interest arises expressly from a foreign enforceable title. Thus, applying the provision of $\mathbb{\int} 54 \mathrm{a}$ ZPO is not permissible with foreign enforceable titles (Jakusch in Angst, Oberhammer, 2015: 82-84). A similar provision regarding interest on the cost part of a claim is also known in the Croatian legal system, namely the provision of the second paragraph of Article 30 of the Croatian Enforcement Act. ${ }^{57}$ Consequently, an Austrian court could allow the enforcement of interest on costs awarded based on a Croatian enforceable title, even if they did not originate from an enforceable title, since Croatian law also has a provision comparable to the Austrian $\int 54 \mathrm{a}$ Paragraph 2 ZPO. However, the Austrian court would not allow the enforcement of interest on awarded costs based on the Slovenian enforceable title if they do not originate from the enforceable title, as the Slovenian legal order does not have such a substantive provision.

\footnotetext{
56 Austrian Supreme Court - OGH 3Ob98/03p of 21 August 2003.

${ }^{57}$ Ovršni zakon (Official Gazette 112/12, 25/13, 93/14, 55/16, 73/17, 131/20).
} 
In all three legal systems (Slovenian, Austrian and Croatian), the court is bound by the enforceable title, so that interest must be enforced by the court according to the substantive law of the country from which the enforceable title originates.

\section{$5 \quad$ Conclusion}

It has been our experience that when the interest part of the claim is to be enforced, it is useful that the interest be specified precisely in the enforceable title, or at least that the data be given based on which the interest can be calculated. Some European countries do not acknowledge the interest part of the claim even in foreign enforceable title, from which only the data set "interest on arrears" results (e.g. Germany). Therefore, it would be useful to "equip" Slovenian enforcement addresses with a more concrete indication of interest (at least with a reference to the law according to which interest is calculated). The descriptive record of "statutory default interest" may be sufficient to enforce a domestic enforceable title in the Republic of Slovenia, but not for enforcement based on a Slovenian enforceable title abroad. We can conclude that the descriptive phrase of "statutory default interest" may not be sufficiently defined with cross-border debt recovery.

Regarding enforcement in the Republic of Slovenia, both regarding domestic and foreign enforceable titles, we can state that, according to the principle of formal legality, the court is bound by the substantive rules of the country from which the enforceable title originates, i.e. the interest rate. Where all the data for determining the interest rate are derived from the enforceable title, the Slovenian Enforcement Court is competent to concretise the interest rate.

\section{References}

Angst, P. and Oberhammer, P. (2015) Kommentar zur Exekutionsordnung, XXXVII (Wien: Manz). Dika, M. (2007) Građansko ovršno pravo (Zagreb: Narodne novine).

Dika, M. (2009) Građansko parnično pravo, Tužba, VI. Knjiga (Zagreb: Narodne novine).

Ekart, A. and Rijavec, V. (2019) Zakon o izvršbi in zavarovanju (ZIZ): z novelo ZIZ-L: razširjena uvodna pojasnila s podrobnim prikazom evropskega naloga za zamrznitev bančnih računov (Ljubljana: Lexpera, GV Založba).

Iglič Stroligo, K. (2009) Preizkus predloga za dovolitev izvršbe, Pravosodni bilten, 30 (1), pp. 111-30. Juhart, J. (1974) Civilno izvršilno pravo: oris (Ljubljana: Univerza).

Juhart, M. (2005) Ureditev zamudnih obresti - nujnost ponovne spremembe, Zbornik Inštituta za primerjalno pravo pri Pravni fakulteti v Ljubljani, pp. 59-66. 
Ljubimski, J. (2011) Bančne skrivalnice neposredno izvršljivih kreditnih obveznosti v izvršbi, Pravna praksa, 30 (41/42), pp. 6-10.

Neumayr, M. and Nunner-Krautgasser, B. (2018) Exekutionsrecht (Wien: Manz).

Rechberger, W. H. and Oberhammer, P. (2009) Exekutionsrecht (Wien: Facultas.wuv).

Rijavec, V. (2003) Civilno izvršilno pravo (Ljubljana: GV Založba).

Rijavec, V. (2008) Izvršba na podlagi tujega izvršilnega naslova, Dnevi slovenskih pravnikov 2008 od 16. do 18. oktobra, Portorož, pp. 993-1009.

Rijavec, V., Brehm, W., Jelinek W., Ekart, A., Keresteš, T., Zangl, S., Spellenberg, U. and Wetzelberger, J. (2012) Die Erleichterung der Zwangsvollstreckung in Europa (Baden-Baden: Nomos).

Rijavec, V., Kennett, W., Keresteš, T. and Ivanc, T. (2018) Remedies concerning enforcement of foreign judgements: Brussels I Recast, XXIV (Alphen aan den Rijn, The Netherlands: Wolters Kluwer).

Sladič, J. (2013) The remedies and recourses in European civil procedure after the intended abolition of the exequatur, ZEuS. Zeitschrift für europarechtliche Studien, 16 (3), pp 329-358

Šinkovec, J. and Tratar, B. (2001) Obligacijski zakonik: s komentarjem in sodno prakso (Lesce: Oziris). Wiedemann, D. (2017) Vollstreckbarkeit: Entwicklung, Wirkungserstreckung und Qualifikation im System Brüssel 1a (Tübingen: Mohr Siebeck).

\section{About the author}

Irena Merc is a senior legal adviser at the District Court in Maribor, e-mail: merc.irena@gmail.com. 
